\title{
Mineralogical and Geochemical Trends in the Residual Soils above Basement Rocks in Ore Area, Southwestern Nigeria
}

\author{
Adewole John Adeola ${ }^{1}$ \& Emmanuel Tamunobelema Tubonemi ${ }^{1}$ \\ ${ }^{1}$ Department of Physical and Earth Sciences, Crawford University, Igbesa, Ogun State, Nigeria \\ Correspondence: Adewole J. Adeola, Crawford University, Igbesa, Ogun State, Nigeria. Tel: 234-8038-120-171. \\ E-mail: johnadeola@crawforduniversity.edu.ng
}

Received: August 9, 2017

Accepted: August 21, $2017 \quad$ Online Published: August 30, 2017

doi:10.5539/jgg.v9n3p42

URL: http://dx.doi.org/10.5539/jgg.v9n3p42

\begin{abstract}
Residual clays and laterite of economic values often occur within weathering profiles above basement rocks in tropical regions due to supergene enrichment and leaching of liable components. Previous studies in Ore area mainly on geochemistry of the basement rocks with scanty information on the weathered profiles. This study was carried out to determine the compositional characteristics of the basement rocks, the geochemical trends within the profiles above the parent rocks and the evaluation of their economic potentials.

Petrographic study was carried out on thin sections of the rock samples. Elemental compositions of the rocks, clay, laterite, and top-soil were determined using Inductively Coupled Plasma-Mass Spectrometer (ICP-MS). Clay mineralogy was determined using X-ray Diffraction (XRD) analysis. Chemical index of Alterations (CIA) was calculated from geochemical data.

Weathering of granite and banded gneiss in Ore resulted in the formation of soil layer, which ranged $0-0.5 \mathrm{~m}$, laterite $1.2-3 \mathrm{~m}$ and clayey zone 2.9-3.0m. Quartz, plagioclase feldspars, microcline, biotite and hornblende were the essential minerals in the parent rocks. Granite and banded gneiss is high $\mathrm{SiO}_{2}(>65 \%)$ but low in $\mathrm{MgO}$ $(<2.0 \%)$ and $\mathrm{CaO}(<4.0 \%)$. Kaolinite $(60-80 \%)$, goethite $(3-12 \%)$ and microcline $(4-10 \%)$ were the dominant minerals in the XRD of the weathering profiles. Traces of illite were present only in granite. The CIA was generally $>85$ indicating advanced state of weathering producing lateritic soil. The lateritic profiles over granite and banded gneiss of Ore area varied with the composition of the parent rocks. The clay layer has economic potential for ceramics, fertilizer and structural wares.
\end{abstract}

Keywords: weathering, laterite, clay, economic potentials, ore deposit

\section{Introduction}

Lateritic soil is a residual soil derived essentially from chemical weathering of igneous and metamorphic rocks under tropical climate. During weathering, decomposition of rock and formation of soil occur simultaneously and are indistinguishable from each other. Thus, soil formation can be considered as an advanced stage of weathering. According to Ola (1983). The chemical compositions of the laterite within a soil profile vary according to the nature of the rock. For example, $\mathrm{Ca}$ and $\mathrm{Mg}$ are dominant in mafic and ultramafic rocks, whereas $\mathrm{K}$ and $\mathrm{Na}$ are released in greater proportions by felsic rocks and argillaceous sediments. Calcium is more likely to be removed than magnesium, which may be adsorbed on clays or incorporated in the structure of smectites or chlorites. Potassium may be retained in muscovite and illite, whereas sodium tends to remain in solution. Iron and manganese are appreciably soluble only under reducing conditions (Hawkes and Webb, 1962; Mason 1966; Kranskopf, 1967; Bradshaw et al, 1973 and Levinson, 1974). Chromium is fairly stable during chemical weathering and is retained in chrome-chlorites and chrome-smectites. Similarly nickel is adsorbed on serpentine and smectite minerals. Cobalt, on the other hand, is associated with manganese minerals and iron oxi-hydroxides.

The Precambrian basement complex of southwestern Nigeria consists predominantly of gneisses, schists and quartzite, which granitic and basic intrusive have been emplaced. Some of the basement rocks have been greatly weathered to form soil as extensive occurrences of such residual bodies have been reported by various workers (Bolarinwa 2006, Elueze and Bolarinwa 1994, Emofurieta et al 1994, Adeola and Dada 2017).

Ore town and its adjourning area falls within the basement complex of Nigeria, the basement rocks have 
weathered to produce profiles of different layers. The average thickness of weathering profiles over the basement rocks in this area ranges between 6 to 8 meters. Exposures of vertical profiles along road cuts in the area distinguished three major horizons in the profile over the basement rocks. The variations in colour, texture and composition of the various zones within the profiles depend on the prevailing chemical environmental conditions, weather it is tending towards laterization or bauxitization. Transition between the zones in the different profiles is gradual. However, depending on the depth of exposure, variable number of weathering horizons could be observed in response to changes in lithology of the various beds. The main focus of this project is to investigate and determine the mineralogical and geochemical trend in the residual soil and evaluate the economic potentials of the weathered products.

\section{Geology of the Area of Study}

The study area falls within the migmatite-gneiss complex of the Basement complex of Nigeria. It forms part of the Pan African mobile belt which lies to the east of West African Craton (Fig.1). Several authors have worked on and classified the basement rocks based on their association and geochronology. Some of the classifications were carried out by Jones and Hockey (1964), Oyawoye (1972) and Oyinloye (2007). Rahaman (1976) classified the basement complex rock units into five different groups: 1) the migmatite - gneiss - quartzite complex; 2) the newer metasediments; 3) Chanockite, diorite and gabbro; 4) Older granite; 5) Unmetamorphosed acid and basic intrusive and hyperbyssal rocks. Rahama (1984) later summarized the geology of Nigeria to three major litho-petrological components, namely the Basement Complex which is made up of Migmatite-Gneiss complex, the schist Belts, the Older Granites, the Younger Granites which comprise of several Jurassic magmatic ring complexes structurally and petrologically distinct from Older Granites centered around Jos and other parts of north-central Nigeria.

In Ore area, banded gneiss is the dominant rock (Fig.2). The mode of occurrences of banded gneiss ranged from low lying outcrops to elevated ridges. Some boulders also scattered closer to their respective parent outcrops. The western side of the study area is predominantly made up strongly foliated banded gneiss, generally grey in color and texturally medium. Banded gneiss has been intruded concordantly and discordantly by quartz and pegmatite veins. Petrographically, it consists of quartz, plagioclase, microcline and biotite (Fig. 3)

Granite is the second abundant rock type in the area. Granite stretches from the north-eastern part to the eastern part of the area. Generally, it is grey in colour and texturally medium grained. The colour is grey and texturally medium grained. Mineralogically, banded gneiss contains both felsic and mafic minerals. The felsic minerals consist of feldspar and quartz, whereas the mafic mineral consists of biotite and hornblende and other accessory minerals. (Fig.4)

\section{Material and Methods}

Rocks, clay, laterite and soil samples were obtained from fresh road cuts at specified intervals from top soil down to fresh basement rocks. Seventy samples comprising 15 each of top-soil, laterite, clay and rock were collected from three lateritic profiles above banded gneiss and granite. Petrographic study was carried out in twelve thin sections of the rock samples. The mineralogy of clay, laterite and soil were determined using X-ray Diffraction (XRD) method. The X-ray diffraction analysis was performed on a Panalytical X'Pert Pro diffractometer, equipped with a $\mathrm{Cu}$ X-ray source and an X'celerator detector, operating at the following conditions: voltage: $40 \mathrm{kV}$; current: $40 \mathrm{~mA}$; range: 5-80 deg 20; step size: $0.017 \mathrm{deg} 2 \theta$; time per step: 50.165 sec; divergence slit: fixed, angle $0.5^{\circ}$. The crystalline mineral phases were identified in X'Pert HighScore Plus using the PDF-4 Minerals 2013 ICDD database at Activation Laboratory in Canada. Elemental compositions of the rocks, clay, laterite and soil samples were determined using Inductively Coupled Plasma-Mass Spectrometer (ICP-MS). For ICP-MS, microwave high pressure/temperature decomposition of samples $\left(230^{\circ} \mathrm{C}, 7.0 \mathrm{Mpa}\right.$; Paar Physical Multiwave sample preparation system) using Merck Suprapurs grade reagents. Chemical Index of Alteration (CIA) was calculated from the elemental data to determine the intensity of weathering. Loss and Gain of electrons were also calculated to determine the degree of mineralization and to evaluate the ore potential of the weathered profiles.

\section{Results and Discussions}

\subsection{Field Work and Macro-Petrography}

Profile 1 is located on granite at Ore via Odigbo town. A 6m thick profile over granite is exposed along Ore-Benin road. This profile is essentially residual and the presence of relic structures of the parent rock and angular quartz grains in the profile strongly supports its insitu nature. There is no evidence of large scale movement and the different horizons within the profile grades smoothly into each other. Four distinct layers were 
identified based on color, texture, and relic structures. The upper horizon which is the topsoil is about $0.5 \mathrm{~m}$ thick, is brown in color contained some organic matter. Directly below this horizon is reddish-brown medium grained laterite layer. It is about $2.5 \mathrm{~m}$ in thickness and grades gradually into the underlying clayey horizon. The clayey layer is about $2 \mathrm{~m}$ thick and contained no organic matter. Underlying the clayey layer is the saprolite horizon characterized by the relic structures of the parent rock (Fig. 5)
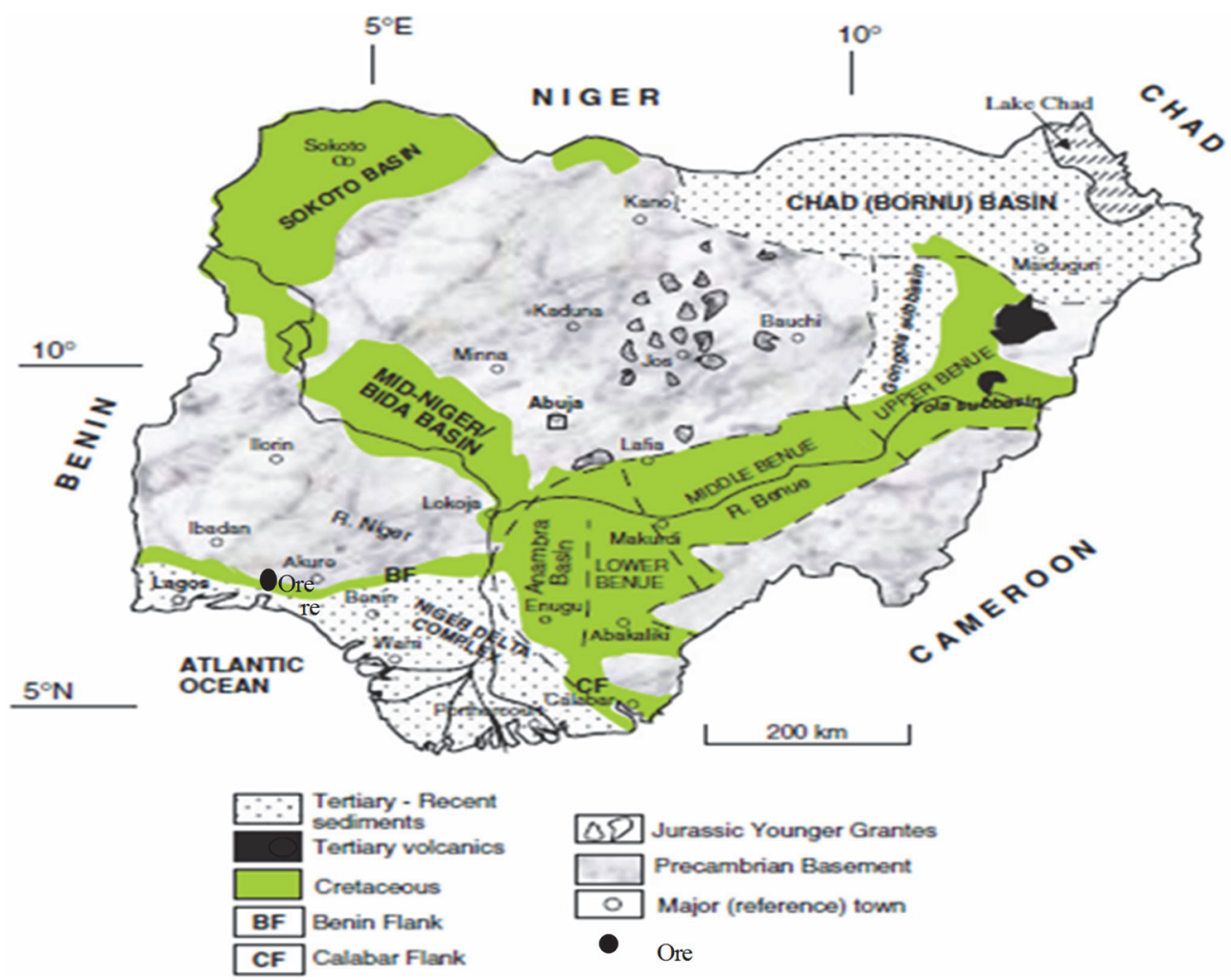

Figure 1. Map of Nigeria showing the location of the study area

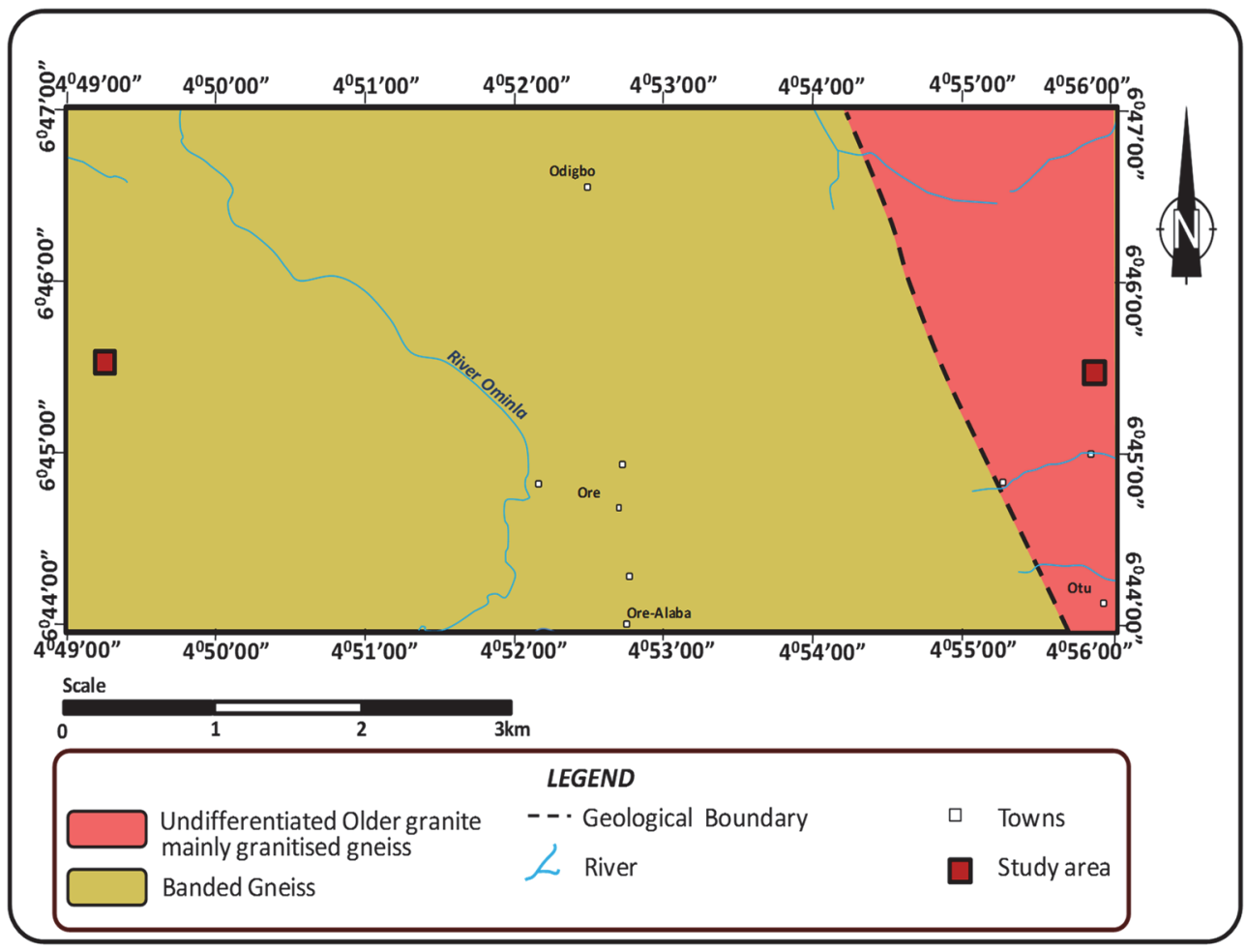

Figure 2. Geologic map of Ore and its environ with the profile locations 


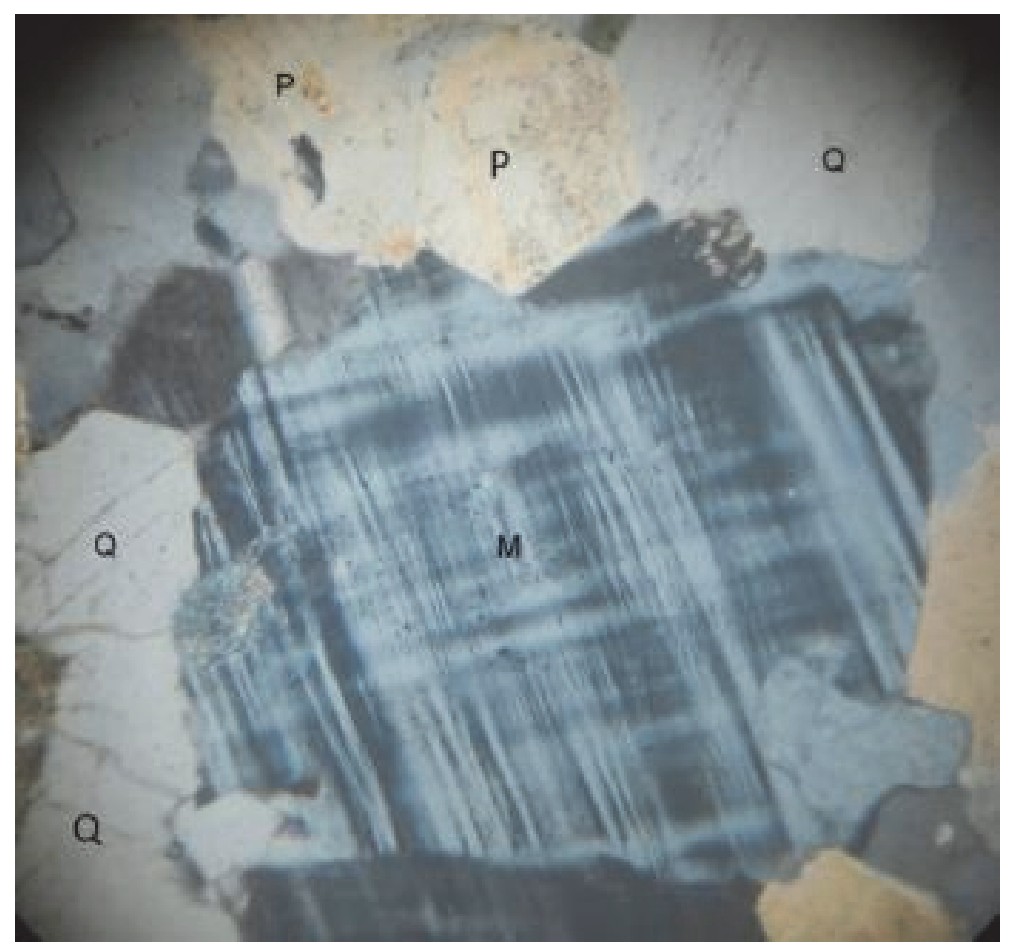

Figure 3. Photomicrograph of banded gneiss showing phenocrystal of microcline embedded in quartz matrix $\mathrm{M}=$ Microcline, $\mathrm{Q}=$ quartz, $\mathrm{P}=$ Plagioclase (under X nicol, Mag. $\mathrm{X} 40$ )

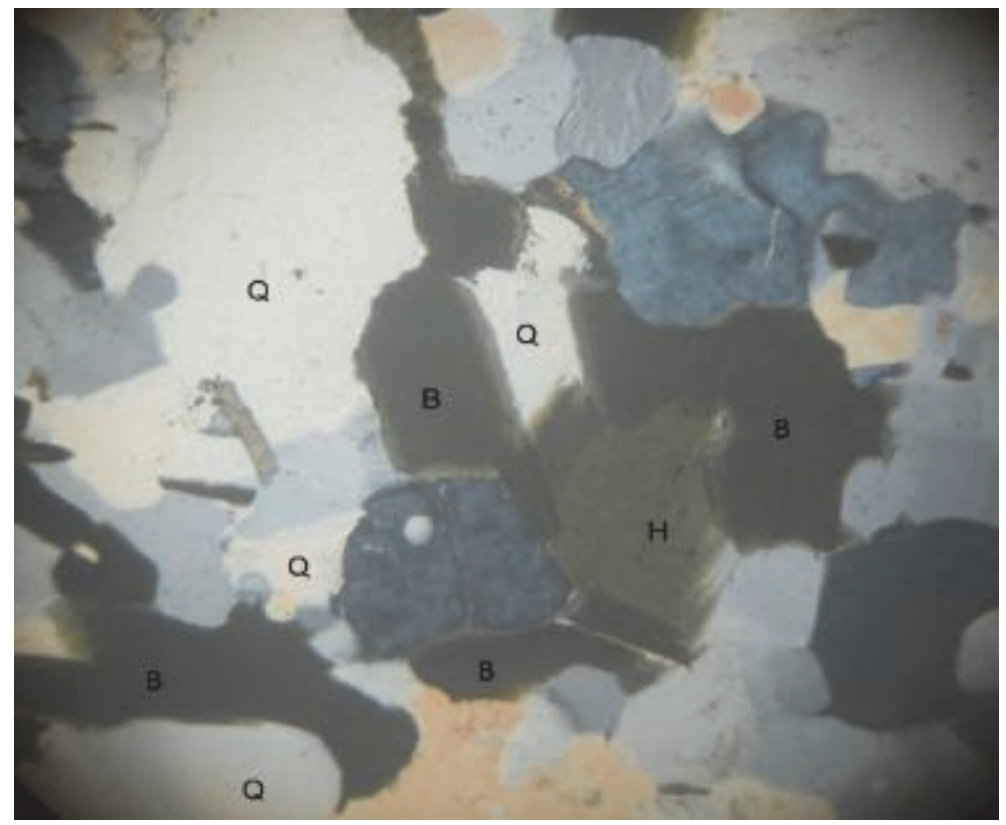

Figure 4. Photomicrograph of granite

$\mathrm{H}=$ Hornblende, $\mathrm{Q}=$ quartz, $\mathrm{P}=$ Plagioclase, $\mathrm{B}=$ Biotite. (under $\mathrm{X}$ nicol, Mag. $\mathrm{x} 40$ )

Profile 2 is located above banded gneiss at the center of Ore town. A $7 \mathrm{~m}$ thick profile is exposed at Ore junction along Lagos - Benin road. The presence of relic structures of the parent rock and angular quartz grains in the profile strongly supports its insitu nature. Similar to the profiles on granite, four distinct layers were identified based on color, texture, and relic structures in the saprolite, (Fig. 6). The topsoil is dark brown in color; medium grained and is about $0.2 \mathrm{~m}$ thick. Directly underlain this horizon is a medium grained reddish-brown laterite layer 
which is about $3 \mathrm{~m}$ in thickness and grades gradually into the underlying clayey horizon. The clayey horizon overlying the saprolite.

\subsection{Mineralogy}

The X-ray diffractograms of soil, laterite and clay on the granite are shown in Fig. 7. Kaolinite is the major clay mineral reflected in the diffractograms of laterite and clay and soil. Conspicuous peaks of non-clayey minerals such as quartz, plagioclase and microcline are recorded by the X-ray chart of the soil sample, while goethite and small quantity of illite are present in the clay and laterite. Quartz is present in all the horizons in this profile because of its high resistance to weathering. The biotite and other ferromagnesian minerals in the parent rock have probably weathered to generate kaolinite and geothite in the laterite (Adeola 2016). The presence of microcline and plagioclase show that weathering is still at incipient stage. Bauxite minerals such as gibbsite, diaspora are absent in this profile. This suggest that the trend of weathering is towards iron enriching (ferralitization) than aluminum accumulation (bauxitization).

The mineralogy of banded gneiss is similar to that of granite. Kaolinite and sepiolite are the major minerals identified in the diffractogram of laterite from banded gneiss (Fig. 8). Also, quartz and kaolinite are the major minerals identified in the clay diffractogram derived from banded gneiss. Due to the absence of bauxite minerals, the weathering is also toward lateritization.

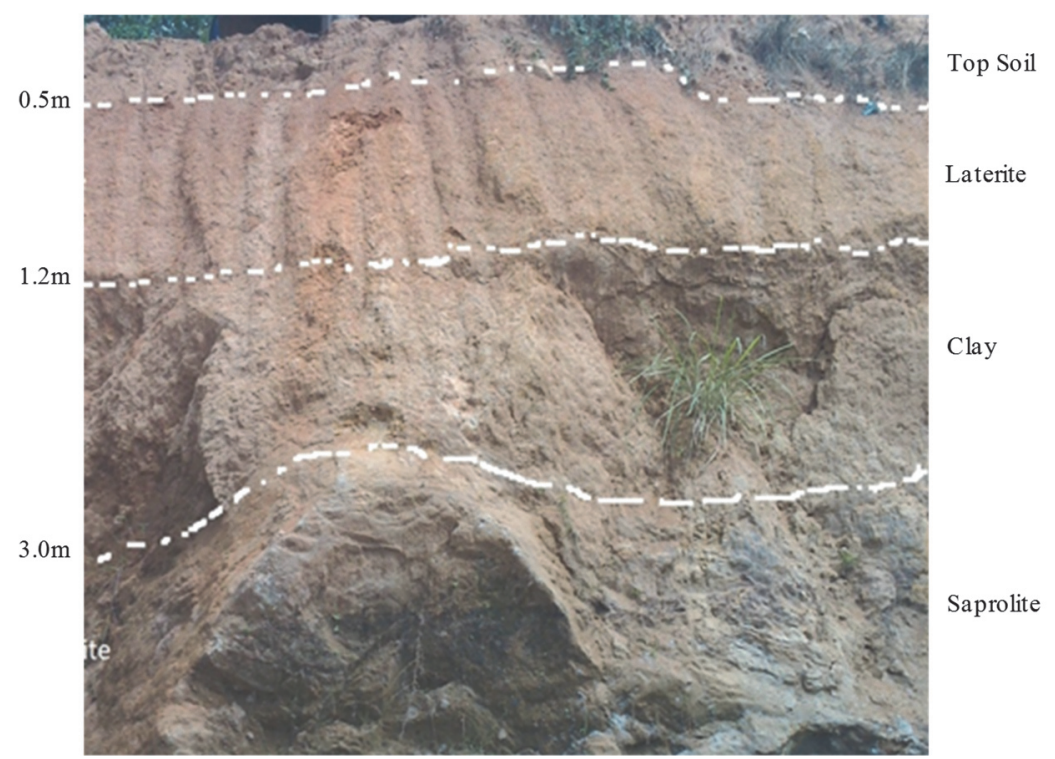

Figure 5. Weathering profile over granite in Ore (Profile 1)

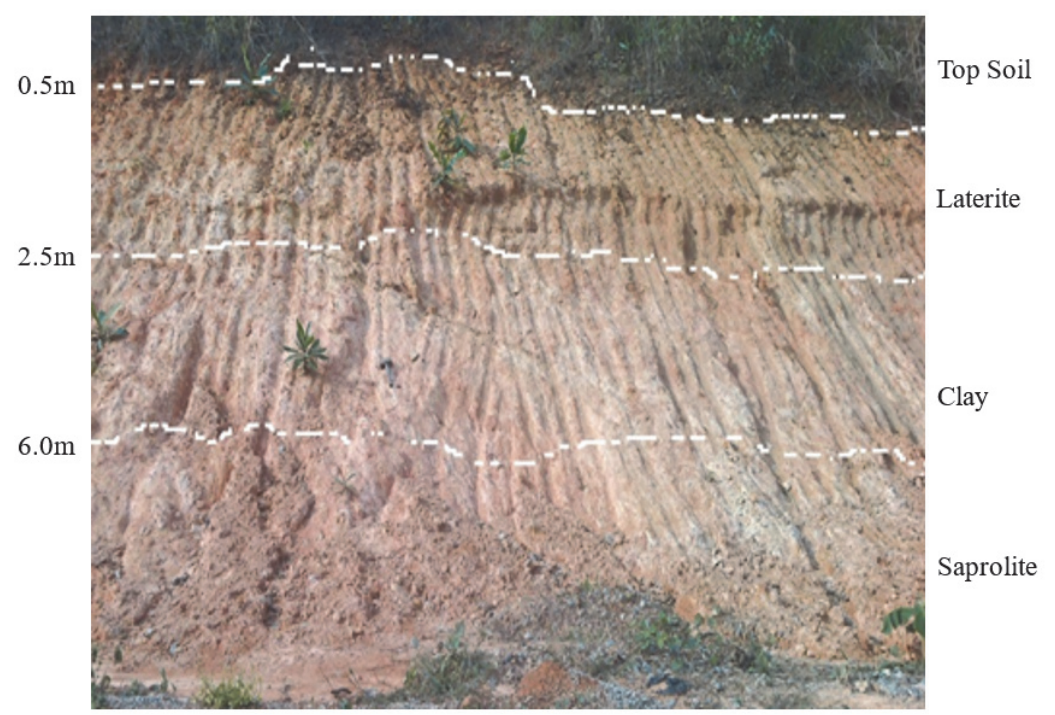

Figure 6. Weathering profile over banded gneiss in Ore (Profile 2) 

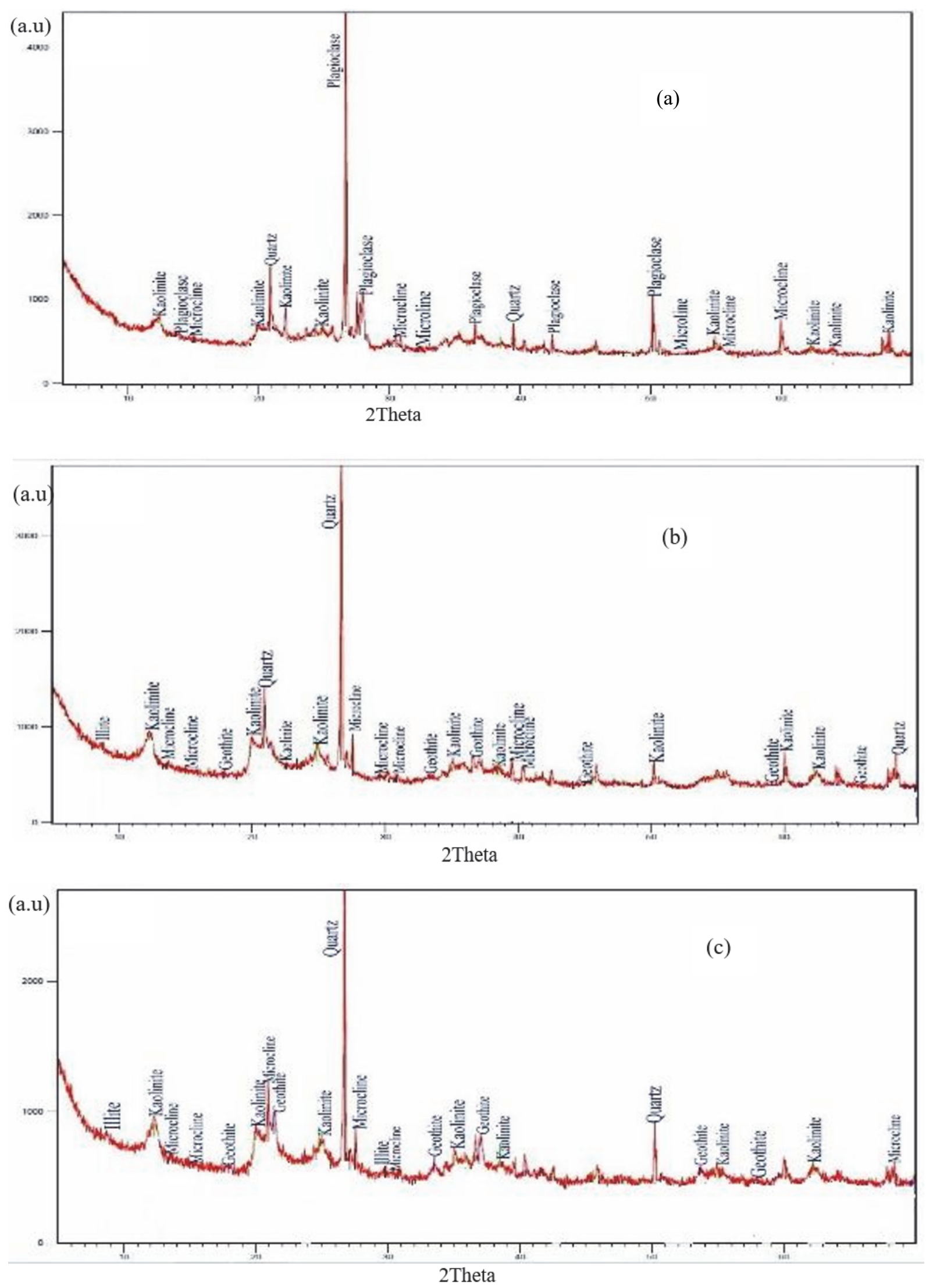

Figure 7. X-ray diffractograms of weathered profile above granite in Ore $\mathrm{a}=$ Soil $\mathrm{b}=$ Laterite $\mathrm{c}=$ Clay $\mathrm{a}$.u. arbitrary units 

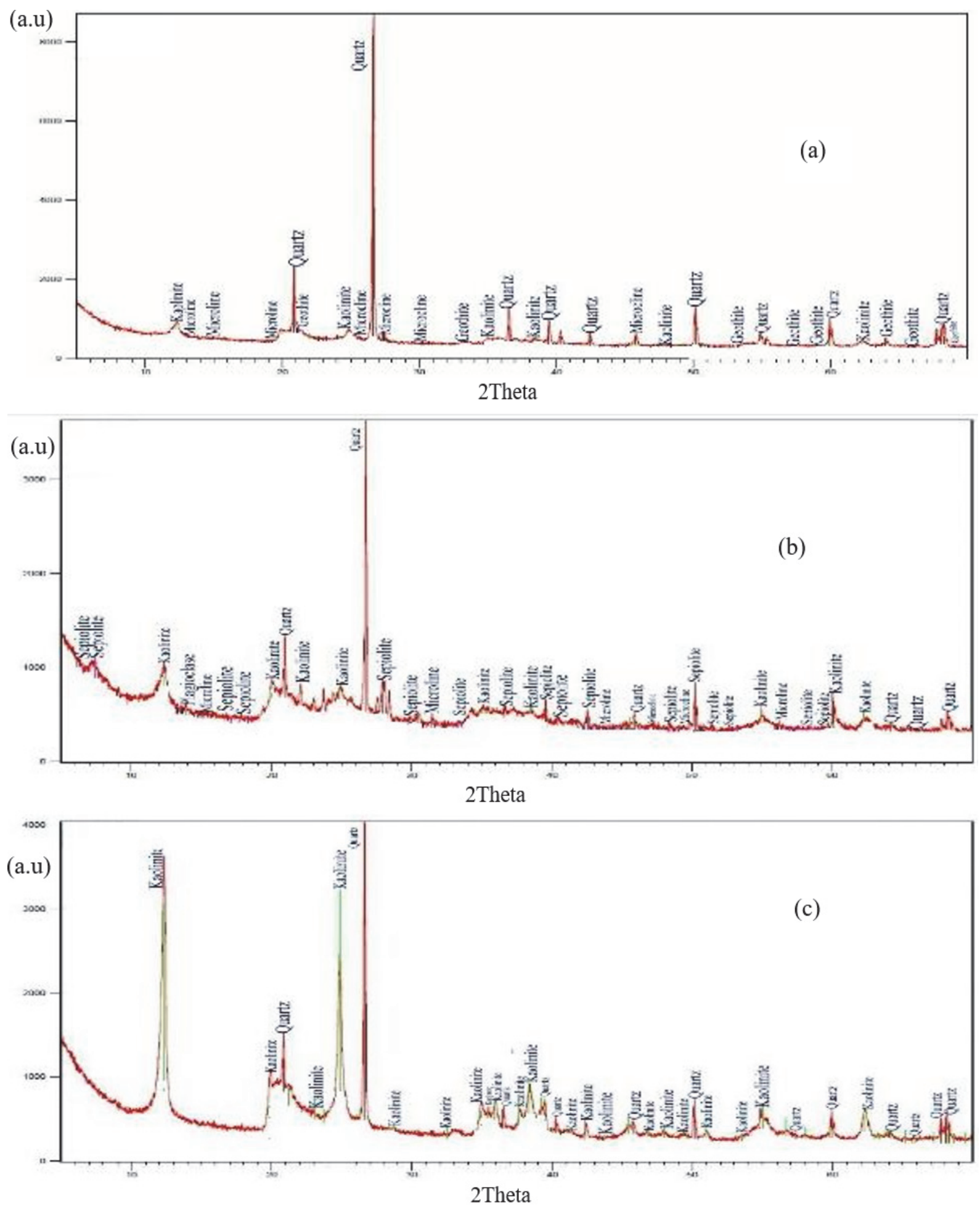

Figure 8. X-ray diffractogram of clay above banded gneiss in Ore

$\mathrm{a}=$ Soil $\mathrm{b}=$ Laterite $\mathrm{c}=$ Clay a.u. arbitrary unit

\subsection{Chemical Compositions.}

\section{Average chemical composition of the weathering profile above granite in Ore.}

The average concentrations of major and trace elements in the weathering profile over granite in Ore are presented in Table (1). The mean compositions of $\mathrm{SiO}_{2}$ are $68.49 \%, 49.55 \%, 50.87 \%$, and $55.48 \%$ in the parent rock, clay, laterite and soil respectively. This shows that relative to the parent rock there has been depletion in the 
$\mathrm{SiO}_{2}$ in the weathering profile. The enhanced value of $55.48 \%$ in the topsoil may be due to the presence of secondary quartz originated from the chemical weathering of rock forming silicates. The weathering and dissolution of these silicate minerals consequently led to the enrichment of $\mathrm{SiO}_{2}$ and $\mathrm{Fe}_{2} \mathrm{O}_{3}$ in the topsoil. The

$\mathrm{X}$-ray diffractogram of the clay, laterite and soil show prominent peaks of quartz than the parent rock probably due to their relative crystallinity (Brindley, 1961).

The average concentration of $\mathrm{Al}_{2} \mathrm{O}_{3}$ are $15.35 \%, 22.24 \%, 22.51 \%, 19.27 \%$ in the parent rock, clay, laterite and topsoil respectively. This indicates an enrichment of $\mathrm{Al}_{2} \mathrm{O}_{3}$ up the profile from the parent rock and the relative enrichment could be as a result of the removal of $\mathrm{MgO}$ and weathering of $\mathrm{Al}_{2} \mathrm{O}_{3}$ bearing minerals such as biotite and hornblende in the granite. The average concentration values of $\mathrm{Fe}_{2} \mathrm{O}_{3}$ are $2.85 \%, 11.15 \%, 8.993 \%, 8.06 \%$ in the parent rock, clay, laterite and topsoil respectively indicating a strong enrichment of $\mathrm{Fe}_{2} \mathrm{O}_{3}$ in the clay, laterite and topsoil compared to the parent rock which is typical of the weathering and laterization of felsic rocks. The enhanced values of the $\mathrm{Fe}_{2} \mathrm{O}_{3}$ concentrations show that the iron bearing minerals such as olivine, biotite, hornblende in the parent rock have decomposed during by chemical weathering to release iron oxides/hydroxides in the weathering horizons.

The values of $\mathrm{MnO}(0.052 \%, 0.029 \%$, to $0.036 \%$, to $0.07 \%)$ and $\mathrm{MgO}(1.18 \%, 0.52 \%, 0.04 \%$ and $0.69 \%)$ show progressive decrease in concentrations in the parent rock, clay, laterite and soil respectively. The low values of $\mathrm{CaO}, \mathrm{Na}_{2} \mathrm{O}, \mathrm{K}_{2} \mathrm{O}$, and $\mathrm{P}_{2} \mathrm{O}_{5}$ strongly indicate leaching through chemical weathering. The depletion of $\mathrm{MgO}, \mathrm{CaO}$, $\mathrm{Na}_{2} \mathrm{O}, \mathrm{K}_{2} \mathrm{O}, \mathrm{P}_{2} \mathrm{O}_{5}, \mathrm{MnO}$ and LOI are pronounced. The concentration values of $\mathrm{CaO}, \mathrm{Na}_{2} \mathrm{O}$ and $\mathrm{P}_{2} \mathrm{O}_{5}$ are $(4.34 \%$, $0.71 \%, 0.10 \% 0.10 \%),(4.95 \%, 1.36 \%, 0.2 \%, 0.27 \%)$ and $(0.14 \%, 0.2 \%, 0.05 \%$, and $0.04 \%)$ in the parent rock, clay, laterite and soil horizon respectively. $\mathrm{MnO}$ and $\mathrm{TiO}_{2}$ also show the same similar trends. This progressive dissolutions and mobility of magnesium, calcium, potassium, sodium has led to their depletions in the weathering profiles (Bolarinwa 2001, Kehinde-Philips 2002). According to Aleva (1994), the decrease in $\mathrm{CaO}$, $\mathrm{Na}_{2} \mathrm{O}, \mathrm{K}_{2} \mathrm{O}, \mathrm{P}_{2} \mathrm{O}_{5}$ and $\mathrm{MnO}$ contents of the weathering profiles relative to the parent rock is due to leaching of these oxides.

The average percentage of trace elements Table (2) show an enhancement of Sr, Zr, Y, Sc, Ba in clay, laterite and soil compared to the parent rock, Although Ba showed depletion from 666 to $651 \mathrm{ppm}$ in clay and decreased to $592 \mathrm{ppm}$ in the laterite and an increase to $989.67 \mathrm{ppm}$ in the topsoil, Sr showed depletion from 94 to $92 \mathrm{ppm}$ in clay and decreased to $88 \mathrm{ppm}$ in the laterite and an increase to 193ppm in the topsoil, $\mathrm{Zr}$ Y and Sc showed similar trends

\section{Average chemical composition of the weathering profile above banded-gneiss in Ore.}

The average concentrations of major and trace elements in the weathering profile over banded-gneiss in Ore are presented in Table (2). The mean compositions of $\mathrm{SiO}_{2}$ are $66.04 \%, 54.44 \%, 50.66 \%$, and $65.51 \%$ in the parent rock, clay, laterite and soil respectively. This shows that relative to the parent rock there has been depletion in the $\mathrm{SiO}_{2}$ in the weathering profile. The enhanced value of $65.513 \%$ in the topsoil may be due to relative depletion of $\mathrm{MnO}, \mathrm{MgO}, \mathrm{CaO}, \mathrm{Na}_{2} \mathrm{O}, \mathrm{K}_{2} \mathrm{O}$ in the horizon and the quartz which could be said to be of secondary origin, probably accumulated from the silica normally generated during chemical weathering of rock forming silicates. This shows that relative to the parent rock there is an increase in silica content in the weathering profile. The weathering and dissolution of these silicate minerals consequently led to the enrichment of $\mathrm{Fe}_{2} \mathrm{O}_{3}$ in the topsoil. The X-ray diffractogram of both the laterite and soil show prominent of quartz than the parent rock. This may probably be to relative crystallinity and not relative concentrations (Brindly 1961). The average concentration values of $\mathrm{Al}_{2} \mathrm{O}_{3}$ are $15.85 \%, 28.36 \%, 24.97 \%, 16.22 \%$ in the parent rock, clay, laterite and topsoil respectively indicating an enrichment of $\mathrm{Al}_{2} \mathrm{O}_{3}$ in the clay and laterite profile compared to the parent rock. From the chemical data, the relative enrichment could be explained by the removal of $\mathrm{MgO}$ and weathering of alumino-silicate bearing minerals of the banded-gneiss. Also, the X-ray diffractograms of the clay indicates that laterite and soil depict lower number of peaks relative to other minerals.

The average concentration values of $\mathrm{Fe}_{2} \mathrm{O}_{3}$ include $4.1 \%, 4.05 \%, 7.017 \%, 6.66 \%$ in the parent rock, clay, laterite and topsoil respectively indicating a strong enrichment of $\mathrm{Fe}_{2} \mathrm{O}_{3}$ in the clay, laterite and topsoil profile compared to the parent rock, which is typical of the weathering and laterization of felsic minerals. The values of the average $\mathrm{Fe}_{2} \mathrm{O}_{3}$ concentration show that the iron bearing minerals biotite and hornblende in the parent rock have probably been affected by chemical weathering to release iron oxides/hydroxides in the weathering horizons. This is typical for the weathering and lateritization of felsic rocks according to Kehinde-Phillips (1991) 
Table 1. Average chemical composition of major (\%) and trace elements (ppm) over granite at Ore

\begin{tabular}{|c|c|c|c|c|c|c|c|c|}
\hline \multirow[b]{2}{*}{ Oxides } & \multicolumn{2}{|l|}{ Rock } & \multicolumn{2}{|l|}{ Clay } & \multicolumn{2}{|c|}{ Laterite } & \multicolumn{2}{|c|}{ Topsoil } \\
\hline & Mean & Range & Mean & Range & Mean & Range & Mean & Range \\
\hline $\mathrm{SiO}_{2}$ & 68.49 & $67.23-69.75$ & 49.55 & $48.86-50.88$ & 50.87 & 50.45-51.29 & 55.48 & 54.13-56.24 \\
\hline $\mathrm{Al}_{2} \mathrm{O}_{3}$ & 15.35 & $14.99-5.17$ & 22.24 & $22.04-22.51$ & 22.51 & $2.22-22.92$ & 19.27 & $18.58-19.91$ \\
\hline $\mathrm{Fe}_{2} \mathrm{O}_{3}$ & 2.85 & $2.56-3.14$ & 11.15 & $11.04-11.26$ & 8.99 & $8.97-9.01$ & 8.06 & 7.66-8.51 \\
\hline $\mathrm{MnO}$ & 0.05 & $0.05-0.06$ & 0.03 & $0.03-0.03$ & 0.04 & $0.03-0.04$ & 0.07 & $0.07-0.08$ \\
\hline $\mathrm{MgO}$ & 1.18 & $1.02-1.34$ & 0.52 & $0.51-0.52$ & 0.35 & $0.34-0.36$ & 0.69 & $0.54-0.79$ \\
\hline $\mathrm{CaO}$ & 4.34 & $3.98-4.71$ & 0.10 & $0.10-0.10$ & 0.10 & $0.1-0.1$ & 0.71 & $0.61-0.78$ \\
\hline $\mathrm{Na}_{2} \mathrm{O}$ & 4.95 & $4.72-5.18$ & 0.27 & $0.26-0.27$ & 0.20 & $0.2-0.2$ & 0.36 & $1.3-1.45$ \\
\hline $\mathrm{K}_{2} \mathrm{O}$ & 2.28 & $2.17-2.30$ & 1.31 & $0.19-1.72$ & 1.83 & $1.74-1.88$ & 0.47 & $0.40-0.67$ \\
\hline $\mathrm{TiO}_{2}$ & 0.73 & $0.16-0.23$ & 0.89 & $0.87-0.91$ & 0.99 & $0.99-1.01$ & 1.02 & $0.85-1.12$ \\
\hline $\mathrm{P}_{2} \mathrm{O}_{5}$ & 0.14 & $0.12-0.17$ & 0.04 & $0.04-0.05$ & 0.05 & $0.05-0.06$ & 0.12 & $0.09-0.14$ \\
\hline LOI & 0.5 & $0.50-0.51$ & 12.5 & $98.85-100.7$ & 13.34 & 98.91-99.98 & 10.59 & $10.28-0.69$ \\
\hline Total & 99.36 & & 99.53 & & 99.27 & & 99.80 & \\
\hline \multicolumn{9}{|c|}{ Trace Elements (ppm) } \\
\hline $\mathrm{Ba}$ & 610.5 & $229-992$ & 658 & $651-666$ & 592 & $570-603$ & 989.67 & $955-1013$ \\
\hline $\mathrm{Sr}$ & 719.5 & $719-720$ & 93.67 & $92-95$ & 88 & $83-91$ & 193.33 & 191-195 \\
\hline Y & 19 & $17-21$ & 16 & $15-17$ & 15.33 & $14-16$ & 31.33 & $28-35$ \\
\hline $\mathrm{Sc}$ & 13 & $15-11$ & 11.67 & $11-12$ & 12 & $12-12$ & 13 & $11-15$ \\
\hline $\mathrm{Zr}$ & 107 & $104-110$ & 348.7 & $399-366$ & 399.7 & $362-438$ & 579 & $534-658$ \\
\hline $\mathrm{Be}$ & & & 2 & $2-2$ & 1.67 & $1.56-2.00$ & 2 & $2-2$ \\
\hline $\mathrm{V}$ & & & 98.67 & $96-101$ & 86.67 & $86-87$ & 61.67 & $60-64$ \\
\hline \multicolumn{9}{|c|}{ Silica and Aluminum ratio (\%) } \\
\hline SR & 3.76 & & 1.48 & $1.47-1.50$ & 1.61 & $1.61-1.63$ & 2.03 & $1.94-2.11$ \\
\hline AR & 5.39 & & 1.99 & $1.98-2.01$ & 2.50 & $2.47-2.54$ & 2.39 & $2.27-2.60$ \\
\hline $\mathrm{MgO}+\mathrm{CaO}$ & 5.10 & & 0.62 & $0.61-0.62$ & 0.45 & $0.44-0.46$ & 1.41 & $1.15-1.57$ \\
\hline $\mathrm{Na}_{2} \mathrm{O}+\mathrm{K}_{2} \mathrm{O}$ & 6.26 & & 2.514 & $2.43-2.57$ & 2.027 & $1.94-2.08$ & 3.78 & $3.6-3.98$ \\
\hline CIA & & & 89.50 & $89.19-89.90$ & 91.30 & $91.1-91.6$ & 81.10 & 79.6-.54 \\
\hline
\end{tabular}
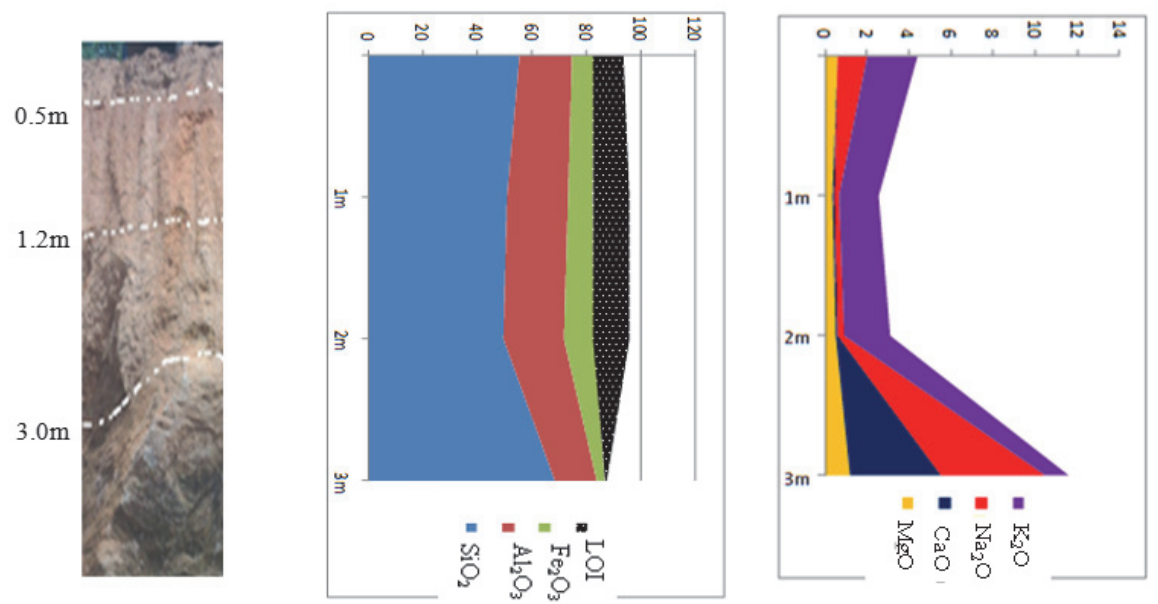

Figure 9. Chemical changes along the vertical profile of granite in Ore area

(Note: The oxides $\mathrm{Fe}_{2} \mathrm{O}_{3}, \mathrm{Al}_{2} \mathrm{O}_{3}, \mathrm{CaO}, \mathrm{Na}_{2} \mathrm{O}$ and $\mathrm{K}_{2} \mathrm{O}$ have the similar geochemical trend).

$\mathrm{MgO}$ content reduce in concentration from $1.28 \%$ in the parent rock to $0.08 \%$ in clay and increased to $1.33 \%$ in the laterite horizon and reduced to $0.11 \%$ in the topsoil. $\mathrm{TiO}_{2}$ content increased from $0.488 \%$ in the parent rock to $0.76 \%$ in the clay horizon and then reduced to $0.69 \%, 0.77 \%$ in the laterite and soil respectively. The slight increase of $\mathrm{MgO}$ in the laterite layer and increase of $\mathrm{TiO}_{2}$ in the laterite profile is due to the high concentration of 
Sepiolite, a hydrous magnesium silicate. The concentration $\mathrm{CaO}, \mathrm{Na}_{2} \mathrm{O} \mathrm{P}_{2} \mathrm{O}_{5}$ decrease from the parent rock to the top soil. This geochemical trend is similar to the weathering of granite and banded gneiss in Ife, Abeokuta, Idiayunre-Ibadan areas reported by Emorforieta et al (1995), Kehinde-phillips and Tietz (1995), Bolarinwa and Elueze (2004) and Bolarinwa and Adeola (2017) and Adeola and Oyebola (2016).

The trend of the average concentrations of trace elements in the different soil profiles are as follows: Ba shows depletion from 666 to $651 \mathrm{ppm}$ in clay and decreases to $592 \mathrm{ppm}$ in the laterite and an increase to $989.67 \mathrm{ppm}$ in the topsoil, $\mathrm{Sr}$ showed depletion from 94 to $92 \mathrm{ppm}$ in clay and decreased to $88 \mathrm{ppm}$ in the laterite and an increase to $193 \mathrm{ppm}$ in the topsoil, $\mathrm{Zr}$ showed increment from 339 to $366 \mathrm{ppm}$ in clay and increased to $399.7 \mathrm{ppm}$ and $579 \mathrm{ppm}$ in the laterite and topsoil respectively. Y values decreased from 17 to $16 \mathrm{ppm}$ in clay and decreased to $15.33 \mathrm{ppm}$ in the laterite and an increase to $31.33 \mathrm{ppm}$ in the topsoil, Sc showed increase from 12ppm in the clay and laterite horizon to $13 \mathrm{ppm}$ in the topsoil.

In banded gneiss, the average values of silica-sequioxide ratio of the rock, clay, laterite and soil vary from 1.58 to 3.31. The Alumina-iron ratio (A.R) ranges from 2.34 to 7.0. The total sum of the alkalis $(\mathrm{MgO}+\mathrm{CaO})$ are 5.52, 0.097, 1.98, 0.12 and $\mathrm{Na}_{2} \mathrm{O}$ and $\mathrm{K}_{2} \mathrm{O}$ are 6.32, 0.35, 2.51, 0.95 in the rock, clay, laterite and soil respectively. The relatively high of $(\mathrm{MgO}+\mathrm{CaO})$ is probably due to high amount of mafic minerals in the rock while the relatively high of $\left(\mathrm{Na}_{2} \mathrm{O}+\mathrm{K}_{2} \mathrm{O}\right)$ is probably due to high amount of plagioclase minerals in the rock.

Ige et.al. (2005). Their corresponding decrease in concentrations in the overlying horizons is due to leaching.

\section{Chemical index of Alteration (CIA) and intensity of chemical weathering (ICW) in the Profiles}

Nesbitt and Young $(1984,1989)$ derived the Chemical Index of Alteration $\left(\mathrm{CIA}=\mathrm{Al}_{2} \mathrm{O}_{3} / \mathrm{Al}_{2} \mathrm{O}_{3}+\mathrm{CaO}+\mathrm{Na}_{2} \mathrm{O}+\right.$ $\left.\mathrm{K}_{2} \mathrm{O}\right) \times 100$, where all components expressed in molecular proportions by) to measure of the intensity of Chemical Weathering (ICW) of soils in the different profiles. Nesbitt indicated that CIA values between 30-55 is an indication of weathering at an incipient stage and CIA values ranging between 51-85 is an indication of weathering at intermediate stage while weathering at an advanced stage would have values greater than 85 . Fresh and unaltered granitic rocks will have CIA values around 50 and plot along plagioclase-K-feldspar or slightly below as shown in the A-CN-K diagram (Fig ), because of the breakdown of plagioclase feldspar during the initial stages of weathering. $\mathrm{Ca}$ and $\mathrm{Na}$ are removed from the weathered rocks and $\mathrm{Al}_{2} \mathrm{O}_{3}$ is increased, as the residual clay mineral is retained in the weathered profile. Also the composition of weathered soil material would move away from $\mathrm{CN}$ corner almost parallel to the A-CN joint. At advanced stage of weathering, $\mathrm{K}$ would be lost from the weathered products resulting in the compositional plot trending towards A-CN joint away from the $\mathrm{K}$ apex. A residual soil rich in clay minerals such as kaolinite would have a CIA value close to 100. Therefore, the position of sample of weathered of weathered products of soil or rocks in the A-CN-K diagram as well as its CIA value would be a good indicator of the extent of chemical weathering experienced by the rock. (Nesbitt and Young, 1984 Anuspam and Rajamani, 1999).Table (4) shows the summary of the average values of the calculated Chemical Index of Alteration (CIA) for the different weathering profiles in Ore area. The CIA values of all samples in Ore area show increasing trend of weathering that have reached the advanced stage. The average CIA values of granitic rock and laterite are 59.1 and 91.3 respectively indicating that granite has experienced high intensity of chemical weathering (Fig. 11). The average values CIA in the rock (60.98), clay (98.7), laterite (88.77) and soil (93.92) shows that weathering has reached advanced stage.

Table 2. Average chemical composition of major (\%) and trace elements (ppm) over banded-gneiss at Ore

\begin{tabular}{lllllllll}
\hline & Rock & \multicolumn{3}{c}{ Clay } & \multicolumn{3}{c}{ Laterite } & \multicolumn{3}{c}{ Soil } \\
\hline Oxides & Mean & Range & Mean & Range & Mean & Range & Mean & Range \\
\hline $\mathrm{SiO}_{2}$ & 66.04 & $66.01-66.21$ & 54.44 & $51.39-59.61$ & 50.66 & $50.07-51.07$ & 65.51 & $65.12-65.82$ \\
$\mathrm{Al}_{2} \mathrm{O}_{3}$ & 15.85 & $15.61-16.09$ & 28.36 & $24.28-31.24$ & 24.97 & $24.58-25.42$ & 16.22 & $15.89-16.62$ \\
$\mathrm{Fe}_{2} \mathrm{O}_{3}$ & 4.1 & $4.08-4.13$ & 4.05 & $3.24-4.59$ & 7.02 & $6.88-7.12$ & 6.66 & $6.55-6.80$ \\
$\mathrm{MnO}$ & 0.47 & $0.46-0.50$ & 0.01 & $0.01-0.01$ & 0.05 & $0.05-0.05$ & 0.02 & $0.02-0.02$ \\
$\mathrm{MgO}$ & 1.28 & $1.22-1.35$ & 0.08 & $0.05-0.12$ & 1.33 & $1.31-1.36$ & 0.11 & $0.11-0.12$ \\
$\mathrm{CaO}$ & 3.82 & $3.86-3.79$ & 0.02 & $02-0.02$ & 0.65 & $0.62-0.67$ & 0.10 & $0.1-0.11$ \\
$\mathrm{Na} 2$ & 4.77 & $4.70-4.85$ & 0.02 & $0.01-0.02$ & 0.87 & $0.83-0.9$ & 0.08 & $0.08-0.09$ \\
$\mathrm{~K}_{2} \mathrm{O}$ & 1.55 & $1.51-1.59$ & 0.33 & $0.17-0.65$ & 1.64 & $1.63-1.65$ & 0.87 & $0.85-0.89$ \\
$\mathrm{TiO}_{2}$ & 0.49 & $0.47-0.49$ & 0.76 & $0.50-0.89$ & 0.69 & $0.68-0.69$ & 0.76 & $0.74-0.79$ \\
$\mathrm{P}_{2} \mathrm{O}_{5}$ & 0.19 & $0.19-0.20$ & 0.03 & $0.02-0.05$ & 0.03 & $0.02-0.04$ & 0.04 & $0.03-0.05$ \\
$\mathrm{LOI}$ & 0.24 & $0.23-0.25$ & 11.58 & $10.43-12.48$ & 11.69 & $11.39-12.03$ & 9.76 & $9.66-9.86$ \\
\hline
\end{tabular}




\begin{tabular}{|c|c|c|c|c|c|c|c|c|}
\hline Total & 98.79 & & 99.68 & & 99.59 & & 100.16 & \\
\hline $\begin{array}{l}\text { Trace } \\
(\mathrm{ppm})\end{array}$ & ements & & & & & & & \\
\hline $\mathrm{Ba}$ & 757.5 & $585-930$ & 68.67 & $38-122$ & 552 & $546-559$ & 220 & $216-225$ \\
\hline $\mathrm{Sr}$ & 780 & $780-780$ & 12.67 & $4-29$ & 136 & $132-140$ & 25.33 & $24-26$ \\
\hline $\mathrm{Y}$ & 2 & $6-6$ & 10.67 & $9-12$ & 26 & $26-27$ & 13.33 & $12-14$ \\
\hline $\mathrm{Sc}$ & 1 & $1-1$ & 9.67 & $8-11$ & 13.67 & $13-14$ & 9 & $9-9$ \\
\hline $\mathrm{Zr}$ & 10.5 & $10-11$ & 691.3 & $421-853$ & 223.3 & $204-246$ & 866.67 & $818-941$ \\
\hline $\mathrm{Be}$ & & & 2 & $2-2$ & 2 & $2-2$ & 1 & $<1-1$ \\
\hline $\mathrm{V}$ & & & 14.67 & $11-19$ & 87.67 & $87-89$ & 51 & $50-52$ \\
\hline \multicolumn{9}{|c|}{ Silica and Alumina Ratio (\%) } \\
\hline SR & 3.31 & & 1.68 & $1.52-2.06$ & 1.58 & $1.54-1.62$ & 2.85 & $2.78-2.92$ \\
\hline AR & 3.87 & & 7.002 & $5.29-9.64$ & 3.56 & $3.5-3.61$ & 2.34 & $2.39-2.47$ \\
\hline $\mathrm{MgO}+\mathrm{CaO}$ & 5.52 & & 0.097 & $0.07-0.14$ & 1.98 & $1.93-2.03$ & 0.12 & $0.21-0.22$ \\
\hline $\mathrm{Na}_{2} \mathrm{O}+\mathrm{K}_{2} \mathrm{O}$ & 6.32 & & 0.35 & $0.18-0.67$ & 2.51 & $2.48-2.53$ & 0.95 & $0.93-0.97$ \\
\hline CIA & 60.98 & & 98.7 & $97.84-99.33$ & 88 & $88.51-89.13$ & 94 & $93.7-93.95$ \\
\hline
\end{tabular}
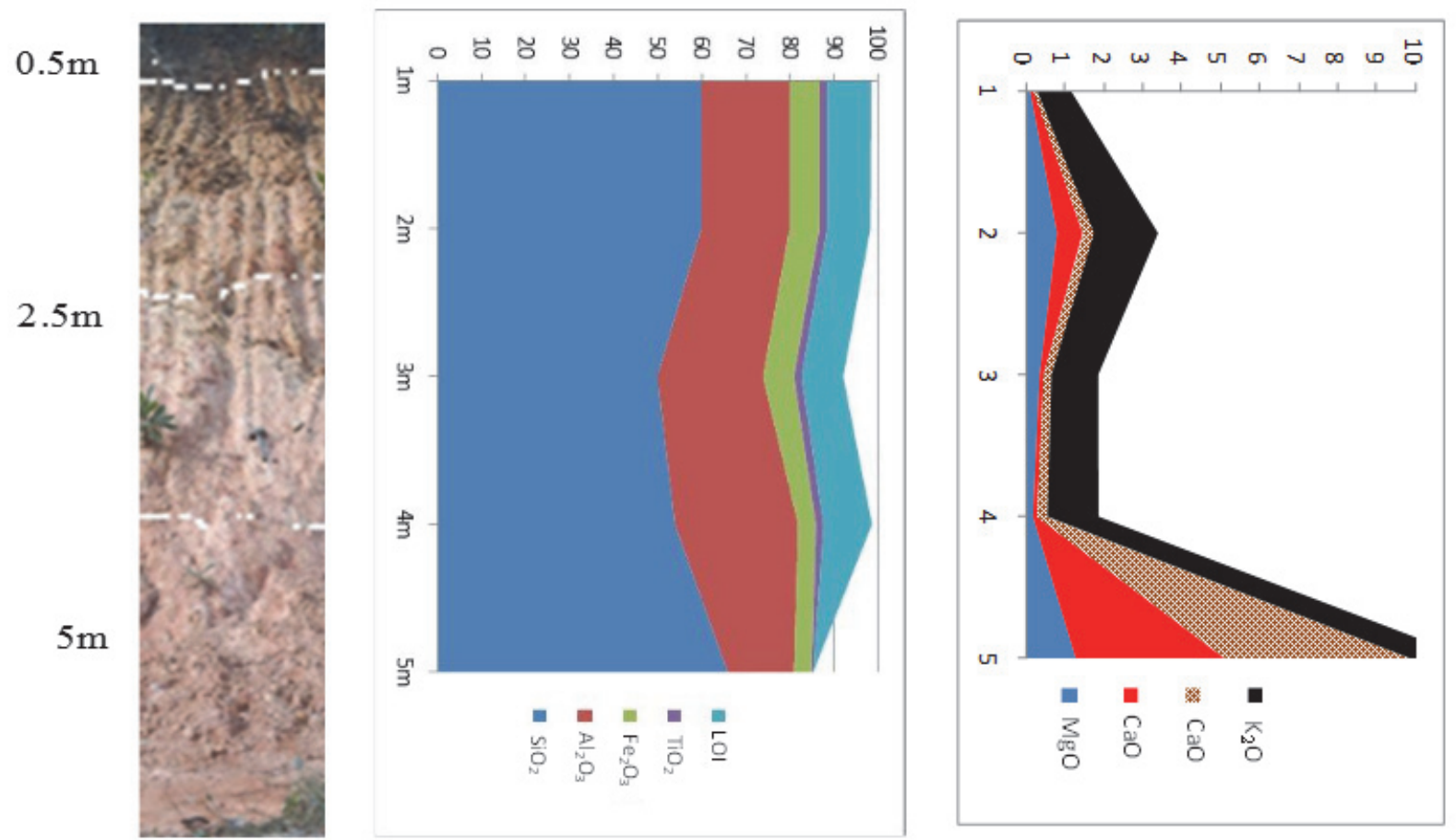

Figure 10. Chemical changes along the vertical profile of banded-gneiss in Ore area.

(Note: The oxides $\mathrm{Fe}_{2} \mathrm{O}_{3}, \mathrm{Al}_{2} \mathrm{O}_{3}, \mathrm{MgO}, \mathrm{CaO}, \mathrm{Na}_{2} \mathrm{O}, \mathrm{K}_{2} \mathrm{O}$ have similar geochemical trend)

\section{Ore Mineralization Potentials of the Lateritic Profiles}

The determination of the economic potentials of the weathering profiles depends on the geochemical variations from the bed rocks to the overlying materials in relation to accumulation according to Nesbitt et al., (1980), Mongelli, (1993), and Kurtz et al., (2000). Minarik et al., (1983), Van der Weijden and Van der Weijden, (1995). Therefore, the indices of accumulation factor (AF) and gain and loss of elements (K) were calculated to determine the presence of any ore mineralization in the weathering profiles. The accumulation factor (AF) and gain and loss of elements $(\mathrm{K})$ in the banded gneiss are presented in Table 5. The AF values it showed that $\mathrm{Al}_{2} \mathrm{O}_{3}$, $\mathrm{Fe}_{2} \mathrm{O}_{3}, \mathrm{TiO}_{2}$ and as well as $\mathrm{Y} \mathrm{Sc}$ and $\mathrm{Zr}$ are enhanced in the clay while $\mathrm{SiO}_{2}, \mathrm{MgO}, \mathrm{K}_{2} \mathrm{O} \mathrm{CaO}, \mathrm{Na}_{2} \mathrm{O}$ and $\mathrm{P}_{2} \mathrm{O}_{5}$ values are less than 1 , an indication that they are grossly depleted compared to bedrock. The same trend was 
observed in the soil except that $\mathrm{Al}_{2} \mathrm{O}_{3}$ is was depleted (Fig. 13). $\mathrm{Al}_{2} \mathrm{O}_{3}, \mathrm{Fe}_{2} \mathrm{O}_{3}, \mathrm{TiO}_{2}, \mathrm{Y}$, Sc and $\mathrm{Zr}$ have been relatively accumulated in the laterite and soil compared to the parent rock. $\mathrm{K}$ values presented in the same Table indicated that nearly all major elements were absolutely depleted in the soil, and laterite with only $\mathrm{Fe}_{2} \mathrm{O}_{3}$ and $\mathrm{Al}_{2} \mathrm{O}_{3}$ showing remarkable enrichment. Though $\mathrm{Al}_{2} \mathrm{O}_{3}$ and $\mathrm{MgO}$ plus $\mathrm{Zr}$ have values equal or greater than 1 , $\mathrm{Al}_{2} \mathrm{O}_{3}$ only retained $69 \%$ of $\mathrm{Al}$ compared to the bedrock, while the laterite does not retain $\mathrm{MgO}$ during chemical weathering. The $\mathrm{K}$ values of the trace elements indicated that trace elements were absolutely depleted in the soil except $\mathrm{Y}, \mathrm{Sc}$ and $\mathrm{Zr}$ which shows slight net concentration. The accumulation factor and loss of elements in granite are as presented in Table 6. There is high concentration of $\mathrm{Fe}_{2} \mathrm{O}_{3}$ in granite than in banded gneiss as depicted by the accumulation factor.. $\mathrm{Al}_{2} \mathrm{O}_{3}$ and $\mathrm{K}_{2} \mathrm{O}$ also accumulated in both laterite and soil above granite in addition to $\mathrm{TiO}_{2}$. Nearly all the trace elements in granite have been depleted from the profile (Fig. 14).

The silica to sequioxide (SR) ratio is used to determine the types of soil formed from the chemical weathering of parent rocks. True laterite is assigned a ratio of 1.33; lateritic soil is assigned a ratio of 1.33 to 2.0 and non-lateritic soil if the value is greater than 2.0 (Nesbitt and Young 1984, 1999, Adeyemi 1992, Adeyemi and Ogundero 2001 and Ola 1984). Results from Table 4.4 show that the SR values of weathered profiles above granite and banded-gneiss are 1.64 and 1.58 respectively. Consequently, the soils formed above them are lateritic soils.

The ternary plots of $\mathrm{SiO}_{2}-\mathrm{Al}_{2} \mathrm{O}_{3}-\mathrm{Fe}_{2} \mathrm{O}_{3}$ of the different profiles shows that the weathering trend is towards laterization rather than bauxitization (Fig ). The absence of Bauxite minerals such as diaspore and gibbsite in all the profiles and the dominance of iron bearing minerals such as goethite in the lateritic horizons and high $\mathrm{Fe}_{2} \mathrm{O}_{3}$ content in their geochemical data proves that the weathering is towards iron enrichment.

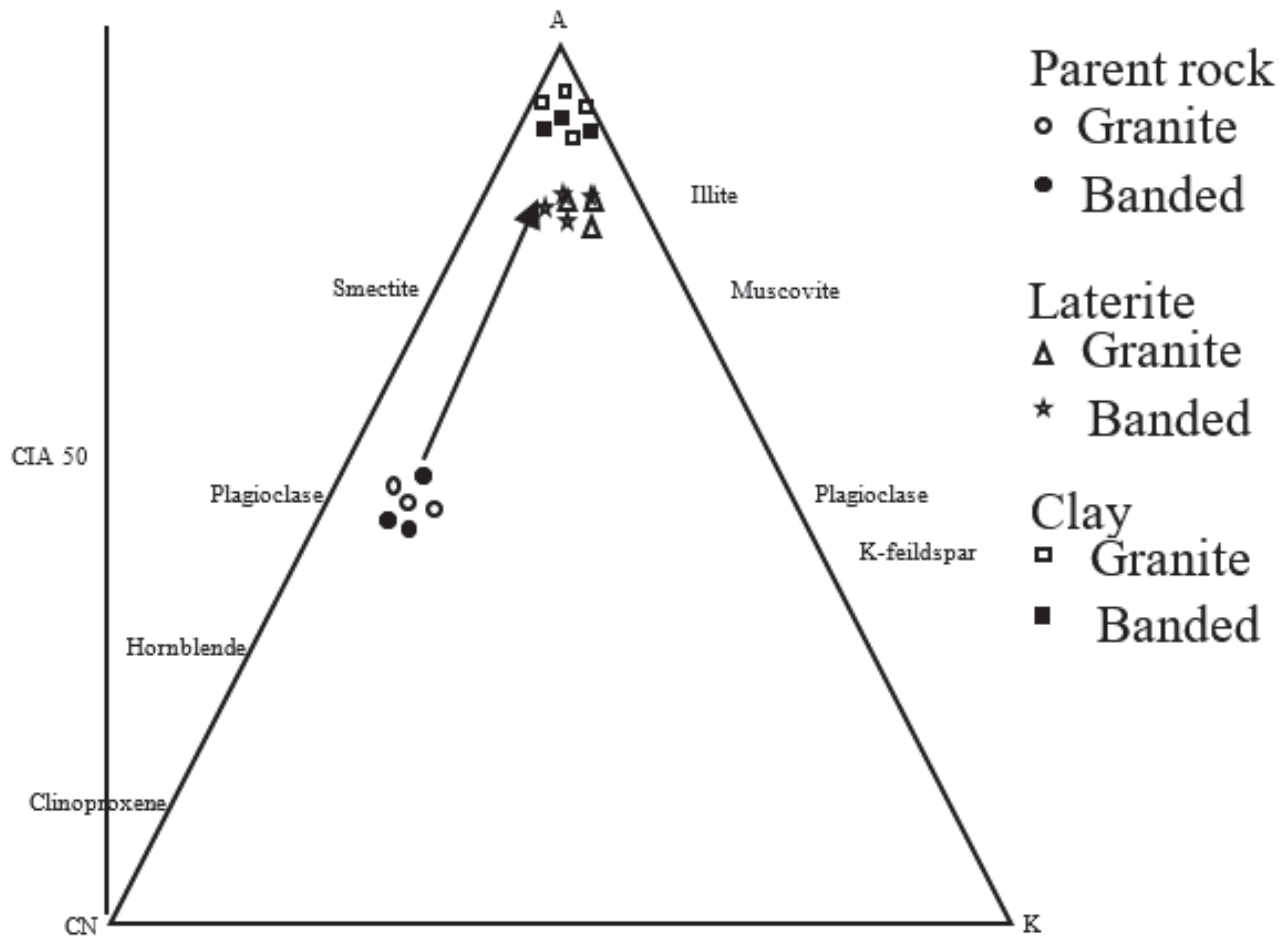

Figure 11. A-CN-K diagram $\left(\mathrm{A}=\mathrm{Al}_{2} \mathrm{O}_{3}, \mathrm{CN}=\mathrm{CaO}+\mathrm{Na}_{2} \mathrm{O}, \mathrm{K}=\mathrm{K}_{2} \mathrm{O}\right)$, all in moles when A-CN-K are recalculated to 100) of weathering profiles from Ore Granite and banded gneiss rocks (After Nesbitt and Young 1984).

Table 3. Mean and range values of Chemical Index of alteration (CIA) over weathering profiles in Ore Area

\begin{tabular}{lccllllll}
\hline & Rock & & \multicolumn{2}{c}{ Clay } & \multicolumn{2}{c}{ Laterite } & Soil \\
\hline Parent Rock & Mean & Range & Mean & Range & Mean & Range & Mean & Range \\
Granite & 59.10 & & 89.50 & $89.20-89.90$ & 91.30 & $91.10-91.60$ & 81.00 & $79.60-82.50$ \\
Banded-gneiss & 60.98 & & 98.70 & $97.84-99.33$ & 88.77 & $85.51-89.13$ & 93.90 & $93.69-93.95$ \\
\hline
\end{tabular}


Table 4. Different types of soil formed over the weathering profiles in Ore.

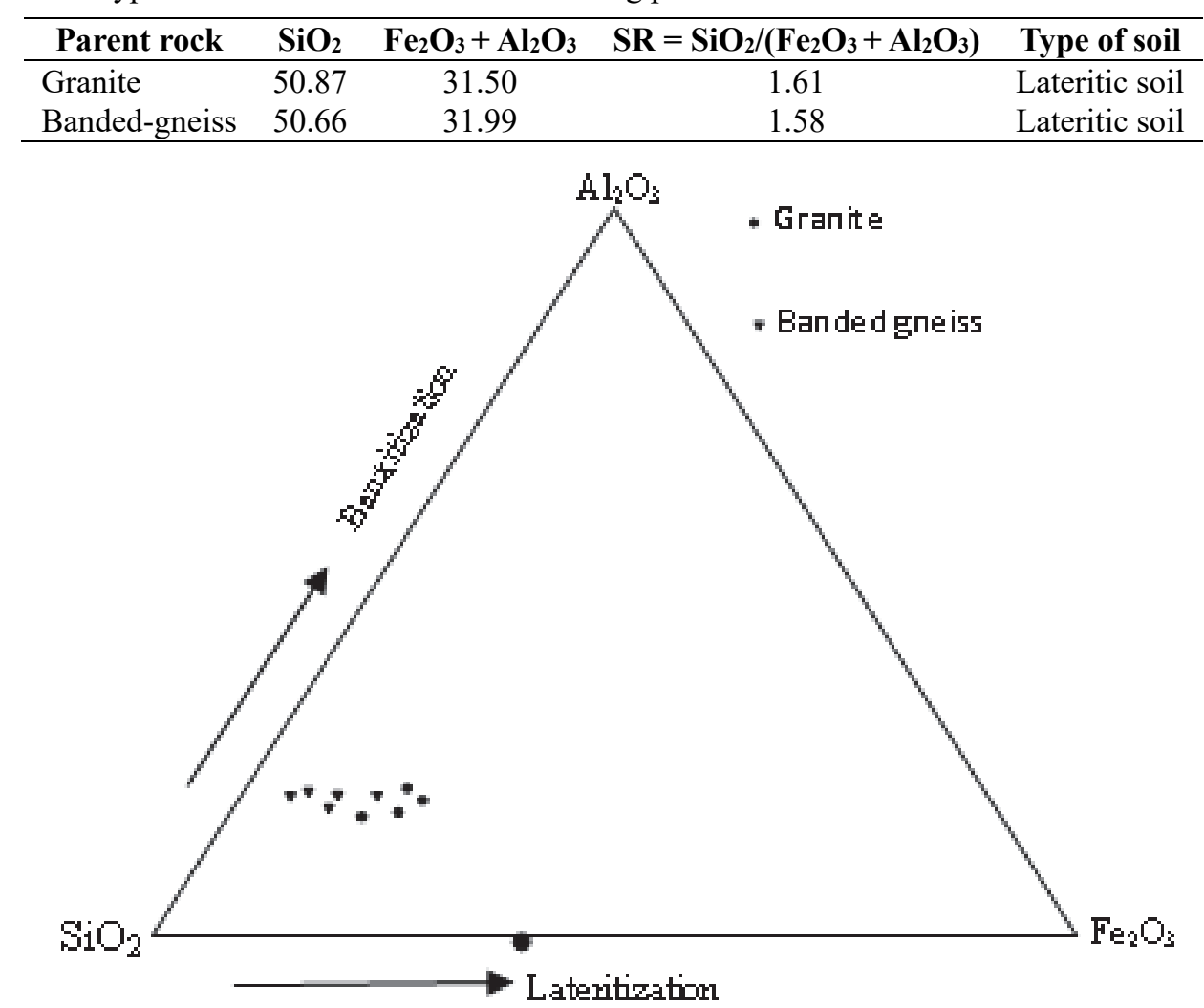

Figure 12. Ternary plot of $\mathrm{SiO}_{2}-\mathrm{Al}_{2} \mathrm{O}_{3}-\mathrm{Fe}_{2} \mathrm{O}_{3}$ o lateritic profiles showing iron enrichment (Lateritization) (after Gardner and Walsh 1996)

Table 5. Accumulation Factor (AF) and Loss and Gain (K) of Elements in profile over Banded gneiss in Ore Area

\begin{tabular}{|c|c|c|c|c|c|c|c|c|c|c|}
\hline \multirow[t]{2}{*}{ ROCK } & \multicolumn{4}{|c|}{ CLAY } & \multicolumn{3}{|c|}{ LATERITE } & \multicolumn{2}{|l|}{ SOIL } & \multirow[b]{2}{*}{$\mathbf{K}$} \\
\hline & Mean & Mean & $\mathbf{A F}$ & $\mathbf{K}$ & Mean & $\mathbf{A F}$ & $\mathbf{K}$ & Mean & $\mathbf{A F}$ & \\
\hline$\overline{\mathrm{SiO}_{2}}$ & 66.04 & 54.44 & 0.82 & -11.24 & 50.7 & 0.77 & -16.5 & 65.51 & 0.99 & $\begin{array}{l}-2.1 \\
\end{array}$ \\
\hline $\mathrm{AL}_{2} \mathrm{O}_{3}$ & 15.85 & 28.36 & 1.79 & 188.64 & 25.00 & 1.58 & 153.1 & 16.22 & 1.02 & 6.00 \\
\hline $\mathrm{FeO}_{3}(\mathrm{t})$ & 4.10 & 4.05 & 0.99 & -2.91 & 7.02 & 1.71 & 189.4 & 6.66 & 1.62 & 161.1 \\
\hline $\mathrm{MnO}$ & 0.47 & 0.01 & 0.02 & -233.91 & 0.05 & 0.11 & -237.7 & 0.02 & 0.04 & -247.0 \\
\hline $\mathrm{MgO}$ & 1.28 & 0.08 & 0.06 & -224.06 & 1.33 & 1.04 & 10.4 & 0.11 & 0.09 & -235.8 \\
\hline $\mathrm{CaO}$ & 3.82 & 0.02 & 0.01 & -237.75 & 0.65 & 0.17 & -220.7 & 0.1 & 0.03 & -251.2 \\
\hline $\mathrm{Na}_{2} \mathrm{O}$ & 4.77 & 0.02 & 0.00 & -238.00 & 0.87 & 0.18 & -217.5 & 0.08 & 0.02 & -253.7 \\
\hline $\mathrm{K}_{2} \mathrm{O}$ & 1.55 & 0.33 & 0.21 & -188.12 & 1.64 & 1.06 & 15.4 & 0.87 & 0.56 & -113.2 \\
\hline $\mathrm{TiO}_{2}$ & 0.49 & 0.76 & 1.55 & 131.69 & 0.69 & 1.41 & 108.6 & 0.76 & 1.55 & 142.2 \\
\hline $\mathrm{P}_{2} \mathrm{O}_{5}$ & 0.19 & 0.03 & 0.16 & -201.26 & 0.03 & 0.16 & -224.0 & 0.04 & 0.21 & -203.7 \\
\hline \multicolumn{11}{|c|}{ Trace Elements } \\
\hline $\mathrm{Ba}$ & 757.5 & 68.67 & 0.09 & -217.33 & 552 & 0.73 & -72.2 & 220 & 0.29 & -183.1 \\
\hline $\mathrm{Sr}$ & 780 & 12.67 & 0.02 & -235.12 & 136 & 0.17 & -219.6 & 25.33 & 0.03 & -249.6 \\
\hline $\mathrm{Y}$ & 2 & 10.67 & 5.34 & 1036.07 & 26 & 13.00 & 3192.0 & 13.33 & 6.67 & 1461.6 \\
\hline $\mathrm{Sc}$ & 1 & 7.7 & 7.70 & 1601.30 & 13.7 & 13.67 & 3370.2 & 9 & 9.00 & 2064.0 \\
\hline $\mathrm{Zr}$ & 11 & 691.3 & 62.85 & 14781.06 & 223 & 20.30 & 5133.8 & 866.7 & 78.79 & 20069.4 \\
\hline $\mathrm{Be}$ & 10 & 2 & 0.20 & -191.20 & 2 & 0.20 & -212.8 & 1 & 0.10 & -232.2 \\
\hline $\mathrm{V}$ & 178.67 & 14.67 & 0.08 & -219.38 & 87.7 & 0.49 & -135.5 & 51 & 0.29 & -184.4 \\
\hline
\end{tabular}



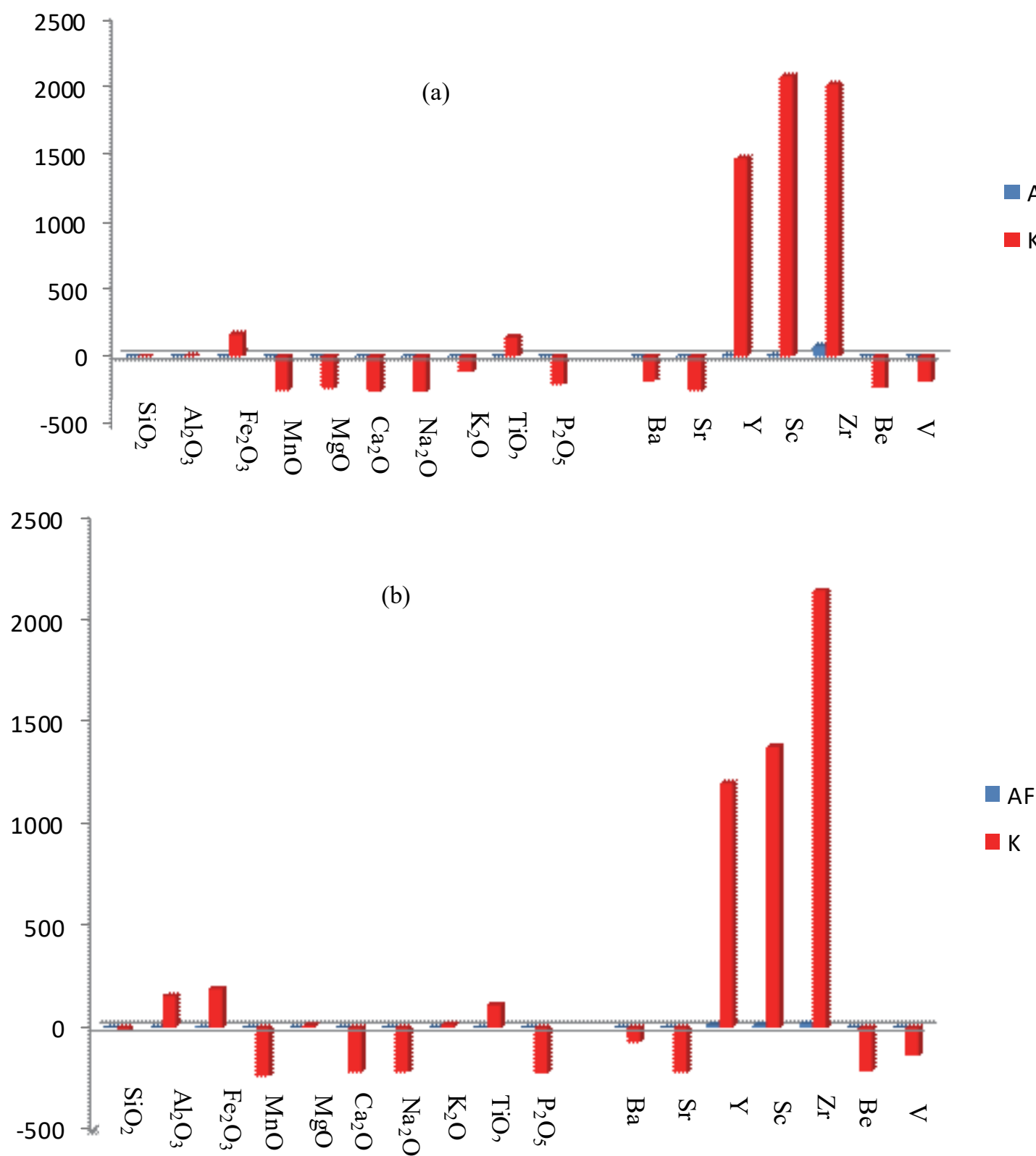

Figure 13. The histogram of AF and $\mathrm{K}$ in weathering profile on banded gneiss in Ore area.

$\mathrm{a}=$ soil, $\mathrm{b}=$ Laterite

Table 6. Accumulation Factor (AF) and Loss and Gain (K) of Elements in profile over granite in Ore Area.

\begin{tabular}{|c|c|c|c|c|c|c|c|c|c|c|}
\hline & \multirow{2}{*}{$\begin{array}{l}\text { ROCK } \\
\text { Mean }\end{array}$} & \multicolumn{3}{|c|}{ CLAY } & \multicolumn{3}{|c|}{ LATERITE } & \multicolumn{3}{|l|}{ SOIL } \\
\hline & & Mean & $\mathbf{A F}$ & $\mathbf{K}$ & Mean & $\mathbf{A F}$ & $\mathbf{K}$ & Mean & $\mathbf{A F}$ & $\mathbf{K}$ \\
\hline $\mathrm{SiO}_{2}$ & 68.49 & 49.55 & 0.72 & -23.23 & 50.87 & 0.74 & -18.8 & 55.48 & 0.81 & -13.5 \\
\hline $\mathrm{AL}_{2} \mathrm{O}_{3}$ & 15.35 & 22.24 & 1.45 & 107.28 & 22.51 & 1.47 & 124.1 & 19.27 & 1.26 & 65.9 \\
\hline $\mathrm{FeO}_{3}(\mathrm{~T})$ & 2.85 & 11.15 & 3.91 & 696.04 & 8.99 & 3.15 & 573.1 & 8.06 & 2.83 & 471.6 \\
\hline $\mathrm{MnO}$ & 0.05 & 0.03 & 0.60 & -95.60 & 0.04 & 0.80 & -53.2 & 0.07 & 1.40 & 103.2 \\
\hline $\mathrm{MgO}$ & 1.18 & 0.52 & 0.44 & -133.68 & 0.35 & 0.30 & -187.1 & 0.69 & 0.58 & -107.1 \\
\hline $\mathrm{CaO}$ & 4.34 & 0.1 & 0.02 & -233.49 & 0.1 & 0.02 & -259.9 & 0.71 & 0.16 & -215.8 \\
\hline $\mathrm{Na}_{2} \mathrm{O}$ & 4.95 & 0.27 & 0.05 & -225.96 & 0.2 & 0.04 & -255.3 & 1.36 & 0.27 & -187.1 \\
\hline $\mathrm{K}_{2} \mathrm{O}$ & 1.31 & 2.25 & 1.72 & 171.50 & 1.83 & 1.40 & 105.6 & 2.42 & 1.85 & 218.6 \\
\hline $\mathrm{TiO}_{2}$ & 0.73 & 0.89 & 1.22 & 52.38 & 0.99 & 1.36 & 94.7 & 1.02 & 1.40 & 102.5 \\
\hline $\mathrm{P}_{2} \mathrm{O}_{5}$ & 0.14 & 0.04 & 0.29 & -170.71 & 0.05 & 0.36 & -171.0 & 0.12 & 0.86 & -36.9 \\
\hline
\end{tabular}




\begin{tabular}{ll|lll|lll|lll}
\hline \multicolumn{1}{l}{ Trace Elements } \\
\hline $\mathrm{Ba}$ & 610.5 & 658 & 1.08 & 18.60 & 592 & 0.97 & -8.1 & 987.67 & 1.62 & 159.4 \\
$\mathrm{Sr}$ & 719.5 & 93.67 & 0.13 & -207.89 & 88 & 0.12 & -233.5 & 193.33 & 0.27 & -188.7 \\
$\mathrm{Y}$ & 19 & 16 & 0.84 & -37.74 & 15.33 & 0.81 & -51.4 & 31 & 1.63 & 162.9 \\
$\mathrm{Sc}$ & 13 & 11.67 & 0.90 & -24.45 & 12 & 0.92 & -20.5 & 13 & 1.00 & 0.0 \\
$\mathrm{Zr}$ & 107 & 348.7 & 3.26 & 539.87 & 399.7 & 3.74 & 727.6 & 579 & 5.41 & 1138.1 \\
$\mathrm{Be}$ & 13 & 2 & 0.15 & -202.23 & 1.67 & 0.13 & -231.8 & 2 & 0.15 & -218.3 \\
$\mathrm{~V}$ & 98 & 98.67 & 1.01 & 1.63 & 86.67 & 0.88 & -30.8 & 61.67 & 0.63 & -95.6 \\
\hline
\end{tabular}

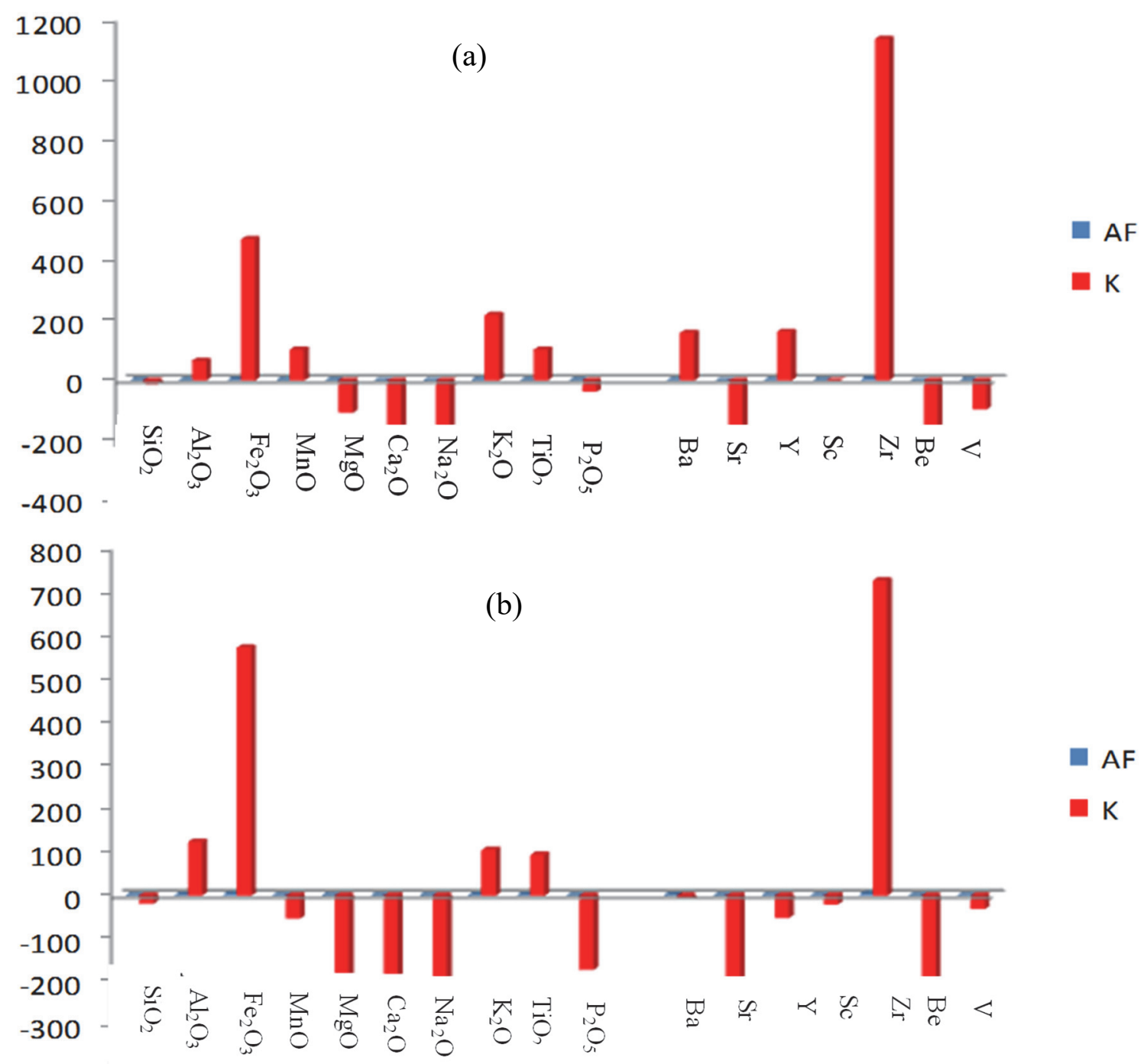

Figure 14. The histogram of AF and $\mathrm{K}$ in weathering profile on granite in Ore area.

$\mathrm{a}=$ soil, $\mathrm{b}=$ Laterite

\section{Conclusion}

Based on the colour, texture and relic structures, the weathered profiles above banded gneiss and granite have three distinct horizons: the top soil, laterite layer which is underlain by clayey zone that graded into the parent rock. In the profile, kaolinite and sepiolite are the major clay minerals whereas hematite, quartz, microcline, plagioclase and goethite constitute the non-clay minerals. The CIA values indicate advanced weathering stage in both banded gneiss and granite. The relative enhancement of iron coupled with the absence of gibbsite and other alumina minerals suggests that the weathering trend is towards lateritization and not baixitization. The soil formed in the profile is classified lateritic soil. The profile above granite show possible iron ore mineralization whereas no evidence of mineralization in banded gneiss profile. 


\section{References}

Adeola, A. J., \& Dada, R. G. (2016). Mineralogy and geochemical trends in lateritic profiles on basement rocks in Awa-Oru -Ijebu and its environ, southwestern Nigeria. Global Journal of Geological Sciences, 15, 1-11.

Adeyemi, G. O. (1992). Highway geotechnical properties of laterised residual soils in the Ajebo-Ishara geological transition zone of southwestern Nigeria. Unpublished Ph.D Thesis. Department of Geology, Obafemi Awolowo University, Ile - Ife, Nigeria.

Adeyemi, G. O., \& Ogundero, O. C. (2001). Some Geotechnical properties of soil developed over migmatite-gneiss in Oru-Ijebu, southwestern Nigeria. Journal of Applied Sciences, 4(3), 2130-2150.

Aleva, G. J. (1994). Laterites; Concepts, Geology, Morphology and Chemistry, ISRIC, Wageningen. 169p.

Aleva, G. J. (1994). Laterites; Concepts, Geology, Morphology and Chemistry, ISRIC, Wageningen, 169p.

Anupam, S., \& Rajamani, V. (2000). Weathering of gneissic rocks in the upper reaches of Cauvery river, south India: implications to neotectonics of the region. Chemical Geology, 166, 203-223.

based on thermodynamic and kinetic. Geochim. Cosmochin. Acta, 48, 1523-1534.

Bolarinwa, A. T. (2001). Compositional characteristics and economic potentials of the lateritic profiles over basement and sedimentary rocks in Ibadan-Abeokuta area, southwestern Nigeria, Unpublished Ph.D. Thesis, University of Ibadan. 255p.

Bolarinwa, A. T. (2006). Mineralogy and geochemistry of the weathering profiles above basement rocks in Ibadan, southwestern, Nigeria. Global Journal of Geological Sciences, 4(2), 183-191.

Bolarinwa, A. T., \& Adeola, A. J. (2017). Geochemistry of Weathered Profiles over Syenite and Younger Granite in Pankshin Area, North Central Nigeria. Earth Science Research, 6(1), 63-78.

Brindley, G. W. (1961). Kaolin, serpentine and kindred Minerals. In Brown, G. (Ed.) The X-ray identification and crystal structure of clay minerals. Mineralogical. Society of London, 544p.

Elueze, A. A., \& Bolarinwa, A. T. (1994). Assessment of function, application of lateritic clay bodies in Ekiti environs, south western Nigeria Journal of Mining and Geology, 31, 79-83.

Emofurieta, W.O., Ogundimu. T.O and Imeokparia, E.G. (1944): Mineralogical, Geochemical and Economic Appraisal of some clay and shale deposits in Southwestern and northeastern Nigeria. Jour. Mineral. Geol., 30(2), 151-159.

Gardner, R., \& Walsh, N. (1996). Chemical weathering of metamorphic rocks from low elevations in southern Himalaya. Chemical Geology, 127, 161-176.

Ige, O. A., Durotoye, B., \& Oluyemi, A. E. (2005). Mineralogy and geochemistry of lateritic weathering profiles on ultramafic rock bodies around Mokuro in Ile-Ife area, southwestern Nigeria. Journal of Mining and Geology, 41(1), 11-18.

Kehinde-Phillips, O. O. (1991). Compositional variations within laterite profiles over mafic and ultramafic rock units of the Ilesha schist belt, Southwestern Nigeria $P h D$. Thesis university of Ibadan, Unpubl. 201p.

Kehinde-Phillips, O. O., \& Tietz, G. F. (1995). The mineralogy and geochemistry of the weathering profiles over amphibolite and Talk-schists in the Ilesha schist belt, southwestern Nigeria Journal of Mining and Geology, $31(1), 53-62$.

Kurtz, A. C., Bormann, F. H., Pierce, R. S., Eaton, J. S., \& Johnson, N. M. (1977). Biogeochemistry of a Forested Ecosystem, Springer-Verlag, New York.146 p.

Martins, F. J., \& Doyne, F. C. (1927), Laterite and lateritic soils in Sierra Leone; Int. Jour, Agric Sci., 17, 530-55.

Minarik, L., Absolom, K., Kollnerova, Z., \& Klecka, M. (1983). Chemical changes of granite during its weathering. In: Augisthitis, S.S. (ed). Leaching and diffusion Rock and their weathering Products. Theophrastus Publicatins, S.A., Athens, Greece. p. 293-306.

Mongelli, G. (1993): REE and other trace elements in a granitic weathering profile from "Serre" southern Italy. Chemical Geology, 103, 17-25.

Nesbitt, H. W., \& Young, G. M. (1984). Prediction of some weathering trends of plutonic and volcanic rocks

Nesbitt, H. W., \& Young, G. M. (1989). Formation and diagenesis of weathering profiles. Journal of Geology, 97(2), 129-147. 
Ola, S. A. (1982). Geotechnical properties and behavior of some Nigeria lateritic soils. Tropical soils of Nigeria In Engineering Practice. Ola S.A. (Ed) p. 61-63

Oyinloye, O. A. (2007). Geology and geochemistry of some crystalline basement rocks in Ilesha area, southwestern Nigeria: Implications on provenance and evolution. Pakistan Journal of Scientific and Industrial Research, 50(4), 233-231.

Rahaman, M. A. (1984). Recent advances in the study of the basement complex of Nigeria. In Precambrian Geology of Nigeria (Eds. Oluyide P.O. et. al.), 241-256.

Van Der Weijden, C. H., \& Van Der Weijden, R. D. (1995). Mobility of major, minor and some redox-sensitive trace elements and rare-earth elements during weathering of four granitoids in central Portugal. Chemical Geology, 125, 149-167.

Walther, J. (1915). Laterite in West- Australian. Zeitschr. D. Geol. Ges., Monatsber, 67B(4), 113-140.

\section{Copyrights}

Copyright for this article is retained by the author(s), with first publication rights granted to the journal.

This is an open-access article distributed under the terms and conditions of the Creative Commons Attribution license (http://creativecommons.org/licenses/by/4.0/). 